\title{
Synthesis, Structural and Antibacterial Study of Some Metal Ion Dithiocarbamate-Azo Complexes
}

\author{
Thanaa J. Al-Hasani, Mustafa K. Al-Taie* \\ Department of Chemistry, College of Science, University of Baghdad, Baghdad-Iraq. \\ * Email: Mustafa5511@yahoo.com
}

\begin{abstract}
Sodium diethyldithiocarbamate (DTC) forms stable colored $\left[\mathrm{M}^{\mathrm{II}}(\mathrm{DTC})_{2}\right]$ complexes where $\mathrm{M}^{\mathrm{II}}=\mathrm{Mn}, \mathrm{Fe}, \mathrm{Co}, \mathrm{Ni}, \mathrm{Cu}$ and $\mathrm{Zn}$. The characterization data suggested square planar geometrical structure for $\mathrm{Co}^{\mathrm{II}}, \mathrm{Ni}^{\mathrm{II}}$ and $\mathrm{Cu}^{\mathrm{II}}$ complexes and a tetrahedral structure for $\mathrm{Mn}^{\mathrm{II}}$, $\mathrm{Fe}^{\mathrm{II}}$ and $\mathrm{Zn}^{\mathrm{II}}$ complexes. Six new complexes of general formula [M(DTC $\left.)_{2} \mathrm{PAN}\right]$ where PAN=1-(2-Pyridyl azo)2-naphthol, were synthesized by using two different routes of preparation. The structures of the complexes are discussed in relation to the analytical, spectroscopic, magnetic and conductivity data. The DTC-ligand exhibits bidentate behavior acting as S,S -donors in all complexes. PAN was also behave as bidentate N,N ligand. The electronic spectra along with magnetic moment values suggested an octahedral structure for [M(DTC $\left.)_{2} \mathrm{PAN}\right]$ complexes. The biological activity for ligands and the prepared complexes were studied against Escherichia Coli, Pseudomonas (G') and Staphylococcus Aureus, Bacillus $\left(\mathrm{G}^{+}\right)$bacteria. Some of the complexes have a relatively strong deactivating capacity against the specimen of bacteria. The presence of PAN ligand increased the inhibition zone.
\end{abstract}

Keyword: Dithiocarbamate, azo complexes, PAN, magnetic moment, N,N` ligand.

\section{1-Introduction}

Dithiocarbamates (DTCs) are versatile chelating ligands with application in industry [1], agriculture [2] and biology [3]. Since the DTCs contain nitrogen and sulphur donor atoms they capable of forming complexes with most of the elements [4]. The $\left(\mathrm{R}_{2} \mathrm{NCS}_{2}{ }^{-}\right)$are the semi-amides of dithiocarbonic acid [5]. The structure of these monoanionic 1,1-dithio ligands can described by four resonance structures [5], as shown below :

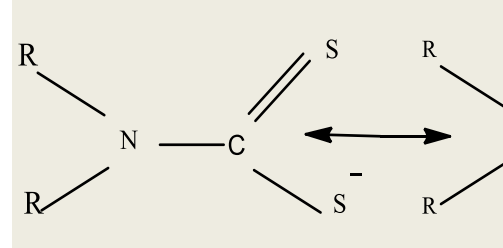

(a)

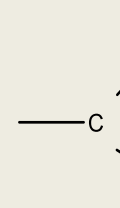

(b)

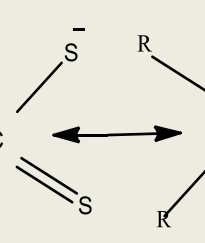

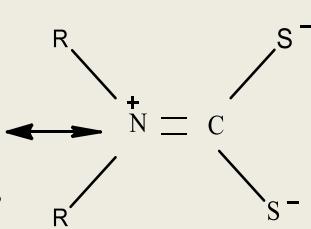

(d)
Manganese dithiocarbamate complexes are known for all oxidation states 1 to 4 , although the nature of manganese (II) complexes, $\left[\mathrm{Mn}\left(\mathrm{S}_{2} \mathrm{CNR}_{2}\right)_{2}\right]$, still remains a topic of some debate [5]. A mixed ligand manganese (II) complexes of the type $\left[\mathrm{Mn}\left(\mathrm{S}_{2} \mathrm{CNR}_{2}\right)_{2}(\mathrm{~L})\right]$ $\left(\mathrm{R}=\mathrm{Et}, \mathrm{C}_{5} \mathrm{H}_{10}, \mathrm{C}_{4} \mathrm{H}_{8} \mathrm{O} ; \mathrm{L}=2,2^{\prime}\right.$-bpy, 1,10phen), are described as adduct [6]. Iron (II) and iron (III) dithiocarbamate complexes, $\left[\mathrm{Fe}\left(\mathrm{S}_{2} \mathrm{CNR}_{2}\right)_{2}\right]$ and $\left[\mathrm{Fe}\left(\mathrm{S}_{2} \mathrm{CNR}_{2}\right)_{3}\right]$, react with $\mathrm{NO}$ to produce $\left[\mathrm{Fe}(\mathrm{NO})\left(\mathrm{S}_{2} \mathrm{CNR}_{2}\right)_{2}\right]$, which are used as trapping agents for the physiologically important molecule [5]. A large number of
Co(II) DTCs are also known and have been prepared from a variety of amines [7]. A series of octahedral cobalt (II) dithiocarbamates with bi- and tetradentate N-donor ligands has been reported, these adducts are pyridine, isoquinoline, $\gamma$-picoline, 3,5-lutidine,1,10phenanthroline and ethylenediamine [8]. Nickel (II) -DTC complexes can also form an octahedral arrangements with a series of $\mathrm{N}$ donor ligands such as 1,10-phenanthroline [8]. The reaction has also been studied spectrophotometrically. Most copper (II) bis (dithiocarbamate) complexes contain a square 
planar copper (II) centre. A number of studies have shown that complexes can be built from simple monomeric units and centrosymmetric dimeric structures which assume the four and five-coordinate geometries with a magnetic moment value of 1.6-1.9 B.M [9]. Zinc (II)-bis (dithiocarbamates) adopt either a monomeric structure or a centro-symmetric dimeric structures in the solid state $[5,7]$. The presence of bulky substituents favours monomeric structures.

On the other hand azo compounds are very important class of chemical compounds receiving attention in scientific research. They are as highly colored and have been used as a dyes and pigments [10] and in various applications such medicines, cosmetics, food, paints, plastics and shipbuilding [10,11]. The characteristic feature of each dye in this class is the chromophoric azo group $(-\mathrm{N}=\mathrm{N}-)$ which form part of the conjugated system and joins two or more aromatic rings [12]. Nheterocyclic azo compounds are among highly sensitive organic reagents, suitable for the spectrophotometric determination of transition metal ions in trace concentrations $[10,13]$. In this group of reagents, 1-(2-pyridyl azo)-2naphthol (PAN) is the most sensitive and promising reagent for determination of many metal ions, including lanthanides [14].

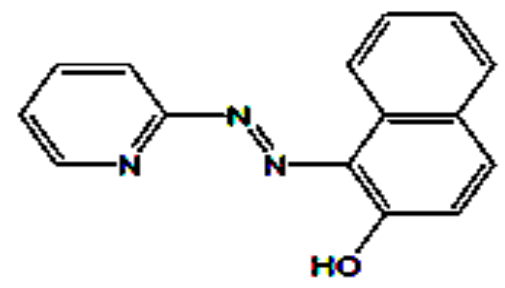

PAN

In view of analysis above interesting survey, we report here the synthesis, spectral characterization and biological activity studies of new $\mathrm{M}^{\mathrm{II}}$-DTC-PAN complexes, where $\mathrm{M}^{\mathrm{II}}=$ $\mathrm{Mn}, \mathrm{Fe}, \mathrm{Co}, \mathrm{Ni}, \mathrm{Cu}, \mathrm{Zn}$, and DTC $=$ diethyldithiocarbamate. The preparation was held on either by the reaction of PAN with the previously prepared $\left[\mathrm{M}(\mathrm{DTC})_{2}\right]$,or, by the direct reaction of the metal salt with DTC and PAN.

\section{2- Experimental}

2-1: Physical measurements

The C.H.N.S analysis were performed at Campbell Microanalytical Laboratory, University of Otago, New Zealand "PerkinElmer 2400 series II CHNS/O Elemental Analyzer". The molar conductivity measurements were obtained using "P.W 9528" Digital Conductometer "HANA H19812 pH/EC/TDS Meter". Magnetic susceptibility was measured at room temperature on a Gouy balance using (Auto Magnetic Susceptibility Balance Sherwood Scientific). Melting point were measured using "Stuart Melting Point Apparatus". The percentage of metal in complexes were performed by flame (Nova AA - 350, Analytik Jena) Atomic Absorption Spectrophotometer. The UV-Vis spectra in ethanol as $10^{-4}$ or $10^{-3}$ $M$ in the range 200-1100nm, were measured using (Shimadzue, UV-1800) UltravioletVisible Spectrophotometer. The FTIR spectra were recorded as $\mathrm{KBr}$ disc in the range 4000$400 \mathrm{~cm}^{-1}$ for the ligands and as CsI disc in the range $4000-200 \mathrm{~cm}^{-1}$ for the complexes using (Shimadzue, FTIR 8400 S).

\section{2-2: Preparation of [M(DTC $\left.)_{2}\right]$}

An aqueous solution of $(5 \mathrm{ml})(0.001 \mathrm{~mole})$ metal salt $\mathrm{MnCl}_{2} .4 \mathrm{H}_{2} \mathrm{O}$ 0.1979gm (BDH), $\left(\mathrm{NH}_{4}\right)_{2} \mathrm{Fe}\left(\mathrm{SO}_{4}\right)_{2} .6 \mathrm{H}_{2} \mathrm{O} \quad 0.2924 \mathrm{gm}$ (Merck), $\mathrm{CoCl}_{2} \cdot 6 \mathrm{H}_{2} \mathrm{O}$ 0.2379gm (Merck), $\mathrm{NiCl}_{2} \cdot 6 \mathrm{H}_{2} \mathrm{O}$ $0.17049 \mathrm{gm}(\mathrm{M} \& \mathrm{~B}), \mathrm{CuCl}_{2} .2 \mathrm{H}_{2} \mathrm{O} 0.2377 \mathrm{gm}$ (Aldrich) or $\mathrm{ZnCl}_{2}$ 0.1362gm (B.D.H), was added dropwise to an aqueous solution $(35 \mathrm{ml})$ of $0.450 \mathrm{gm} \quad(0.002 \mathrm{~mole})$ of sodium diethyldithiocarbamate (Aldrich). The reaction mixture was stirred at room temperature for 23 hours. The formed colored precipitate was filtered, washed with water then with $1: 1 \mathrm{EtOH} /$ water mixture and dried at $50^{\circ} \mathrm{C}$.

\section{2-3: Preparation of $\left[\mathrm{M}(\mathrm{DTC})_{2} \mathrm{PAN}\right]$ Complexes}

These complexes were synthesized by two ways:-

\section{2-3-1: By the Addition of DTC and PAN solutions to Metal Salts Solution (Direct method)}

A solution mixture of $0.450 \mathrm{gm}(0.002$ mole) DTC dissolved in distilled water $(35 \mathrm{ml})$ 
and ethanolic solution $(45 \mathrm{ml})$ of $0.24927 \mathrm{gm}$ (0.001mole) PAN (Fluka) was added to an aqueous solution $(5 \mathrm{ml})$ of $(0.001 \mathrm{~mole})$ metal salts, $\quad \mathrm{MnCl}_{2} .4 \mathrm{H}_{2} \mathrm{O} \quad 0.197 \mathrm{gm}$, $\left(\mathrm{NH}_{4}\right)_{2} \mathrm{Fe}\left(\mathrm{SO}_{4}\right)_{2} \cdot 6 \mathrm{H}_{2} \mathrm{O} \quad 0.292 \mathrm{gm}, \mathrm{CoCl}_{2} \cdot 6 \mathrm{H}_{2} \mathrm{O}$ $0.23793 \mathrm{gm}, \mathrm{NiCl}_{2} .6 \mathrm{H}_{2} \mathrm{O} 0.2771 \mathrm{gm}$ or $\mathrm{ZnCl}_{2}$ $0.1362 \mathrm{gm}$. The reaction mixture was stirred at room temperature, the formed colored precipitate, filtered off, washed with water, then with 1:1 EtOH /water mixture and dried at $50{ }^{\circ} \mathrm{C}$.

\section{2-3-2 By the Reaction of [M(DTC)2] complex with PAN(Indirect method)}

An ethanolic solution $(45 \mathrm{ml})$ of $0.24627 \mathrm{gm}$ (0.001 mole) PAN was added to ethanolic solution $(45 \mathrm{ml})$ of $(0.001 \mathrm{~mole})$ [Mn(DTC $\left.)_{2}\right]$ $0.351 \mathrm{gm},\left[\mathrm{Fe}(\mathrm{DTC})_{2}\right] 0.3523 \mathrm{gm},\left[\mathrm{Co}(\mathrm{DTC})_{2}\right]$ $0.3555 \mathrm{gm}, \quad\left[\mathrm{Ni}(\mathrm{DTC})_{2}\right] \quad 0.3553 \mathrm{gm}$ or [Zn(DTC $)_{2}$ ] $0.3619 \mathrm{gm}$ as a $1: 1$ [M(DTC $\left.)_{2}\right]$ : PAN ratio. The solution mixture was stirred for (1-2) hours. Colored precipitate was formed, filtered off, washed several times with water then with ethanol and dried at $50^{\circ} \mathrm{C}$.

\section{2-4: Antibacterial activity}

Biological activity of compounds in $10^{-4}$ DMSO were measured using four types of bacteria Escherichia Coli, Pseudomonas (G-) and Staphylococcus Aureus ,Bacillus $\left(\mathrm{G}^{+}\right)$ bacteria.

\section{3-Results and discussion}

The reaction of the metal salts with the ligands may be depicted by the following equations

$\mathrm{MCl}_{2} \cdot \mathrm{nH}_{2} \mathrm{O}+2 \mathrm{NaDTC} \rightarrow \mathrm{M}(\mathrm{DTC})_{2}+2 \mathrm{NaCl}+$ $\mathrm{nH}_{2} \mathrm{O}$

$\mathrm{M}^{\mathrm{II}}=\mathrm{Mn}, \mathrm{Co}, \mathrm{Ni}, \mathrm{Cu}, \mathrm{Zn}, \mathrm{n}=4,6,6,2,0$

respectively.

$\left(\mathrm{NH}_{4}\right)_{2} \mathrm{Fe}\left(\mathrm{SO}_{4}\right)_{2} \cdot 6 \mathrm{H}_{2} \mathrm{O}+2 \mathrm{NaDTC} \rightarrow \mathrm{Fe}(\mathrm{DTC})_{2}$ $+\mathrm{Na}_{2} \mathrm{SO}_{4}+\left(\mathrm{NH}_{4}\right)_{2} \mathrm{SO}_{4}+6 \mathrm{H}_{2} \mathrm{O}$

All the complexes were stable in air and not hygroscopic, soluble in most organic solvents. The analytical and spectral studied data, suggest a molecular formula $\left[\mathrm{M}(\mathrm{DTC})_{2}\right]$ for all prepared complexes. The CHNS elemental analyses were in a good agreement with the above suggested formula. The molar conductivity measurements of $10^{-4} \mathrm{M}$ in ethanol and DMF displayed zero or low values for $\Lambda \mathrm{m}$ supporting the neutral behavior of these complexes, Table (1).

There is a wide spread controversial about the geometrical structure of M-DTC complexes in the literature, especially for $\mathrm{Mn}^{\mathrm{II}}$, $\mathrm{Fe}^{\mathrm{II}}$ and $\mathrm{Cu}^{\mathrm{II}}$ complexes [9] the suggested structures were not confirmed by convincing analytical data. The investigation data obtained in this work has revealed that all the prepared $\mathrm{M}^{\mathrm{II}}$-DTC complexes have four coordination geometrical structure, they are either square planar or tetrahedral, thus, these complexes are capable to extend their coordination number.

New complexes of $\mathrm{M}^{\mathrm{II}}$-DTC-PAN have been obtained by two different methods, the direct method which was represented by the direct reaction of the metal salts with both ligands in a mole ratio of 1:2:1 M:DTC:PAN.

$\mathrm{MCl}_{2} \cdot n \mathrm{H}_{2} \mathrm{O}+2 \mathrm{NaDTC}+\mathrm{PAN} \rightarrow$

$\left[\mathrm{M}(\mathrm{DTC})_{2} \mathrm{PAN}\right]+\mathrm{nH}_{2} \mathrm{O}+2 \mathrm{NaCl}$

$\mathrm{M}^{\mathrm{II}}=\mathrm{Mn}, \mathrm{Co}, \mathrm{Ni}, \mathrm{Zn} \mathrm{n}=4,6,6,0$ respectively. $\left(\mathrm{NH}_{4}\right)_{2} \mathrm{Fe}\left(\mathrm{SO}_{4}\right)_{2} \cdot 6 \mathrm{H}_{2} \mathrm{O}+2 \mathrm{NaDTC}+\mathrm{PAN} \rightarrow$ $\left[\mathrm{Fe}(\mathrm{DTC})_{2} \mathrm{PAN}\right]+6 \mathrm{H}_{2} \mathrm{O}+\mathrm{Na}_{2} \mathrm{SO}_{4}+\left(\mathrm{NH}_{4}\right)_{2} \mathrm{SO}_{4}$

and the indirect method which was represented by the addition of PAN to the previously prepared $\left[\mathrm{M}(\mathrm{DTC})_{2}\right]$ complexes in a 1:1 ratio according to the following reaction equation.[M(DTC $\left.)_{2}\right]+\mathrm{PAN} \rightarrow\left[\mathrm{M}(\mathrm{DTC})_{2} \mathrm{PAN}\right]$

Many attempts have been made for the reaction of $\mathrm{Cu}^{\text {II }}$-DTC with the PAN. No reaction was obtained by the two methods. This is may be due to the disability of $\mathrm{Cu}^{\mathrm{II}}$ ion to extend its coordination number with these type of ligands or because of the polymeric structure of the $\left[\mathrm{Cu}(\mathrm{DTC})_{2}\right]$.

The final study results suggests that each complex prepared by the two methods has the same properties and formula. All the prepared complexes are dark colored, air-stable, insoluble in water and soluble or partially soluble in most organic solvents. Fair solubility was achieved in DMF and DMSO. Some of physical and analytical data were tabulated in Table 1. The elemental analysis support the chemical formula [M(DTC) $\left.)_{2} \mathrm{PAN}\right]$ for all complexes. The low values of $\Lambda_{\mathrm{m}}$ for $10^{-4} \mathrm{M}$ DMF solution of these complexes at $25^{\circ} \mathrm{C}$ indicate the non-electrolyte behavior of these complexes. 
Thanaa J. Al-Hasani 


\section{3-1: Electronic spectra}

The UV-Vis spectra of the ligands and their complexes of $10^{-4} \mathrm{M}$ solution in ethanol were recorded. The DTC spectrum showed three peaks at $205 \mathrm{~nm} \quad\left(48780 \mathrm{~cm}^{-1}\right), 258 \mathrm{~nm}$ $\left(38760 \mathrm{~cm}^{-1}\right)$ and $291 \mathrm{~nm}\left(34364 \mathrm{~cm}^{-1}\right)$. These peaks assigned to the intra-molecular intraligand transitions corresponding to $\left(\pi \rightarrow \pi^{*}\right)$ of the $\mathrm{N}-\mathrm{C}=\mathrm{S}$ system, $\left(\pi \rightarrow \pi^{*}\right)$ of the $\mathrm{S}-\mathrm{C}=\mathrm{S}$ group and $\left(\mathrm{n} \rightarrow \pi^{*}\right)$ located on sulphur respectively [15]. On the other hand PAN ligand spectrum exhibits two peaks at $225 \mathrm{~nm}$ $\left(44444 \mathrm{~cm}^{-1}\right)$ and $304 \mathrm{~nm}\left(32895 \mathrm{~cm}^{-1}\right)$ which assigned to the moderate $\left(\pi \rightarrow \pi^{*}\right)$ transitions of the aromatic rings. A third high intense $\lambda$ max peak was observed at $464 \mathrm{~nm}\left(21552 \mathrm{~cm}^{-1}\right)$ which was related to the $\left(\pi \rightarrow \pi^{*}\right)$ transition of intermolecular charge-transfer taken place through the azo group $(-\mathrm{N}=\mathrm{N}-)$. Another peak was also observed as a shoulder at (410-415) $\mathrm{nm}$ may be attributed to $\left(\mathrm{n} \rightarrow \pi^{*}\right)$ transition.

The electronic spectrum of [Mn(DTC $)_{2}$ ] complex showed peak at $351 \mathrm{~nm}\left(28490 \mathrm{~cm}^{-1}\right)$ belong to charge transfer, another two weak peaks were observed at $909 \mathrm{~nm}\left(11001 \mathrm{~cm}^{-1}\right)$ and $487 \mathrm{~nm}\left(20534 \mathrm{~cm}^{-1}\right)$ assigned to the ${ }^{6} \mathrm{~A}_{1} \rightarrow{ }^{4} \mathrm{~T}_{1(\mathrm{G})} \quad$ and $\quad{ }^{6} \mathrm{~A}_{1} \rightarrow{ }^{4} \mathrm{~T}_{2(\mathrm{G})} \quad$ transitions respectively support the tetrahedral structure of this complex. The magnetic moment of 5.693B.M. confirm the tetrahedral structure of [Mn(DTC $)_{2}$ ] [16]. The UV-Vis spectra for the prepared [Mn(DTC) $\left.{ }_{2} \mathrm{PAN}\right]$ complex showed three peaks at $552 \mathrm{~nm}\left(18115 \mathrm{~cm}^{-1}\right), 520 \mathrm{~nm}$ $\left(19230 \mathrm{~cm}^{-1}\right)$ and $398 \mathrm{~nm} \quad\left(25125 \mathrm{~cm}^{-1}\right)$ assignable to ${ }^{6} \mathrm{~A}_{1} \mathrm{~g} \rightarrow{ }^{4} \mathrm{~T}_{1} \mathrm{~g}(\mathrm{G}),{ }^{6} \mathrm{~A}_{2} \mathrm{~g} \rightarrow{ }^{3} \mathrm{~T}_{1} \mathrm{~g}$ (G) and ${ }^{6} \mathrm{~A}_{2} \mathrm{~g} \rightarrow{ }^{3} \mathrm{~T}_{2} \mathrm{~g} \quad(\mathrm{P})$ transitions, respectively,[17]. The magnetic moment of the complex, 5.897 B.M is an additional evidence for an octahedral structure.

The UV-Vis spectrum of the [Fe(DTC $\left.)_{2}\right]$ complex represented by the presence of a weak split peak at $583 \mathrm{~nm}\left(17153 \mathrm{~cm}^{-1}\right)$ and $505 \mathrm{~nm}\left(19802 \mathrm{~cm}^{-1}\right)$ which belongs to ${ }^{5} \mathrm{E}_{(\mathrm{D})} \rightarrow{ }^{5} \mathrm{~T}_{2}$ (D) transition[16]. The magnetic moment 4.782B.M. is within the range of high- spin tetrahedral Fe(II) complexes. The magnetic moment of [Fe(DTC) $\left.{ }_{2} \mathrm{PAN}\right]$ complex has been found to be 4.753 B.M, which is within the range of values corresponding to high-spin octahedral complexes of iron(II). The $\lambda$ max which belongs to the $\left(\pi \rightarrow \pi^{*}\right)$ transition of PAN ligand, $465 \mathrm{~nm}\left(21505 \mathrm{~cm}^{1}\right)$, was shifted by about 40nm to higher wave length and appeared at $504 \mathrm{~nm}\left(19841 \mathrm{~cm}^{-1}\right)$ the other peak at $769 \mathrm{~nm}\left(13003 \mathrm{~cm}^{-1}\right)$ was assigned to the electronic transition type ${ }^{5} \mathrm{~T}_{2} \mathrm{~g}$ $\rightarrow{ }^{5} \mathrm{E}_{1} \mathrm{~g}$ [18].

The electronic spectrum of [Co(DTC $\left.)_{2}\right]$ complex showed only one peak at 634 $\mathrm{nm}\left(15773 \mathrm{~cm}^{-1}\right)$ which is a result of the typical ${ }^{4} \mathrm{~A}_{2} \mathrm{~g} \rightarrow{ }^{4} \mathrm{~T}_{1} \mathrm{~g}$ transition for square planar complexes [19]. The magnetic moment of 1.82B.M support the presence of one unpaired electron in the outer shell of $\mathrm{Co}$ (II) ion in complex and this confirm the suggested square planar geometry of $\left[\mathrm{Co}(\mathrm{DTC})_{2}\right]$ complex. The magnetic moment of [Co(DTC $\left.)_{2} \mathrm{PAN}\right]$ complex was found to be 3.30 B.M which indicate a high-spin $\mathrm{d}^{7}$ octahedral geometry. The electronic spectra also support the octahedral symmetry around Co(II) and this represent by presence of the split peak at $624 \mathrm{~nm}\left(16025 \mathrm{~cm}^{-1}\right)$ and $581 \mathrm{~nm}\left(17211 \mathrm{~cm}^{-1}\right)$ which are tentatively assigned to ${ }^{4} \mathrm{~T}_{1} \mathrm{~g}(\mathrm{~F}) \rightarrow$ ${ }^{4} \mathrm{~T}_{2} \mathrm{~g}(\mathrm{~F})$ and ${ }^{4} \mathrm{~T}_{1} \mathrm{~g}(\mathrm{~F}) \rightarrow{ }^{4} \mathrm{~A}_{2} \mathrm{~g}(\mathrm{~F})$ transitions respectively [18].

The UV-Vis spectrum of [Ni (DTC) $)_{2}$ complex exhibited two d-d transition peaks at $552 \mathrm{~nm}\left(18116 \mathrm{~cm}^{-1}\right)$ and $627 \mathrm{~nm}\left(15949 \mathrm{~cm}^{-1}\right)$ which were ascribed to the ${ }^{1} \mathrm{~A}_{1} \mathrm{~g} \rightarrow{ }^{1} \mathrm{~B}_{2} \mathrm{~g}$ and ${ }^{1} \mathrm{~A}_{1} \mathrm{~g} \rightarrow{ }^{1} \mathrm{~A}_{2} \mathrm{~g}$ transitions. The appearance of two d-d transition peaks in addition to the diamagnetic character of this complex, which was represented by zero value of the magnetic moment will verify the square planar structure of this complex [20]. The electronic spectrum of $\left[\mathrm{Ni}(\mathrm{DTC})_{2} \mathrm{PAN}\right]$ complex revealed three absorptions appeared at $917 \mathrm{~nm}\left(10905 \mathrm{~cm}^{-1}\right)$

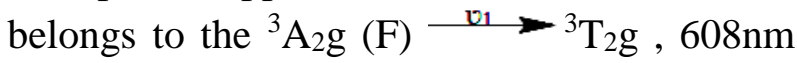
$\left(16447 \mathrm{~cm}^{-1}\right.$ ) assignable to ${ }^{3} \mathrm{~A}_{2} \mathrm{~g}(\mathrm{~F}) \stackrel{\mathrm{O}_{2}}{\longrightarrow}{ }^{3} \mathrm{~T}_{1} \mathrm{~g}$ (F) and $390 \mathrm{~nm}\left(25641 \mathrm{~cm}^{-1}\right)$ assigned to $^{3} \mathrm{~A}_{2} \mathrm{~g}$ (F) $\quad{ }^{3}-{ }^{3} \mathrm{~T}_{1} \mathrm{~g} \quad$ (P) transition. In this spectrum, Figure 1, it is clear that the $\left(\mathrm{n} \rightarrow \pi^{*}\right)$ and $\left(\pi \rightarrow \pi^{*}\right)$ of PAN ligand are shifted to higher wave length and appeared at $524 \mathrm{~nm}$ $\left(19083 \mathrm{~cm}^{-1}\right)$ and $562 \mathrm{~nm} \quad\left(17794 \mathrm{~cm}^{-1}\right)$ respectively. The peak at $324 \mathrm{~nm}\left(30864 \mathrm{~cm}^{-1}\right)$ was related to charge transfer transition. The magnetic moment value of 2.743 and 2.941B.M. for $\mathrm{Ni}^{\mathrm{II}}$ complexes ,prepared by the two methods, is in a good agreement for the suggested high-spin octahedral symmetry [21].The UV-Vis spectrum of [Cu(DTC $)_{2}$ ] complex exhibited two d-d transition bands at 
$433 \mathrm{~nm}\left(23095 \mathrm{~cm}^{-1}\right)$ and $653 \mathrm{~nm}\left(15314 \mathrm{~cm}^{-1}\right)$ which were ascribed to the ${ }^{2} \mathrm{~B}_{1} \mathrm{~g} \rightarrow{ }^{2} \mathrm{~A}_{1} \mathrm{~g}$ and ${ }^{2} \mathrm{~B}_{1} \mathrm{~g} \rightarrow{ }^{2} \mathrm{E}_{2} \mathrm{~g}$. These two transitions are belongs to a square planar structure. The magnetic moment of this complex was 1.923B.M [5], which can be discussed in terms of C.F.T.

The UV-Vis spectrum of [Zn(DTC $\left.)_{2}\right]$ complex showed no d-d bands as expected for $\mathrm{d}^{10}$ complexes because of no empty d-orbitals. In the spectrum of the [Zn(DTC $\left.)_{2} \mathrm{PAN}\right]$ complex, the shift of the $\lambda$ max peak of PAN ligand, which belongs to $\left(\pi \rightarrow \pi^{*}\right)$ transition, is very clear. The peak suffered bathocromic shift with splitting by about $(50-80) \mathrm{nm}$ the complex is diamagnetic and likely to be octahedral [18].

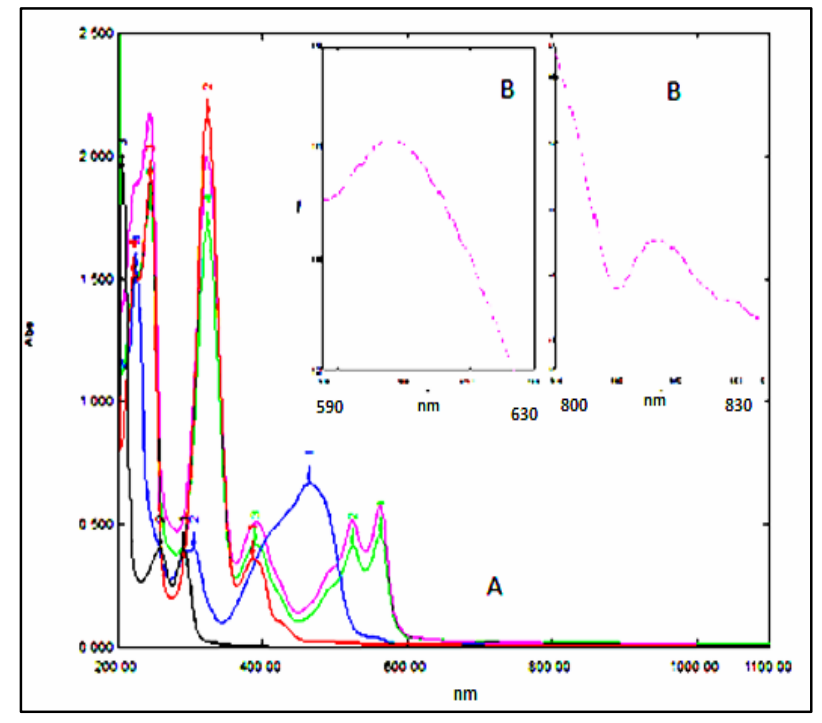

Fig.(1) $U V$-Vis spectra of (A) $10^{-4} M$ ethanolic solution of DTC (---), PAN (---), $\left[\mathrm{Ni}(\mathrm{DTC})_{2}\right](---),\left[\mathrm{Ni}(\mathrm{DTC})_{2} \mathrm{PAN}\right] \operatorname{method}(1)$ (--), [Ni(DTC) 2 PAN] method (2) (---), (B) 10-

${ }^{3} \mathrm{M}$ ethanolic solution of $\left[\mathrm{Ni}(\mathrm{DTC})_{2} \mathrm{PAN}\right]$. 


\section{3-2: FTIR Spectra}

The important IR bands of the ligands and their complexes are listed in Table (3). The stretching frequency of the $v(C-N)$ band for the free dithiocarbamates was intermediate between the stretching frequencies associated with typical single and double-bonded carbon and nitrogen atoms [22]. The $v(\mathbf{C} \cdots \mathbf{N})$ was appeared in the diethyldithiocarbamate spectrum as a doublet at 1477 and $1456 \mathrm{~cm}^{-1}$ and it was shifted toward higher frequencies in all $\left[\mathrm{M}(\mathrm{DTC})_{2}\right]$ complexes and in all [M(DTC) $\left.)_{2} \mathrm{PAN}\right] \quad$ complexes. Another characteristic stretching frequency in DTCs spectra is the $v(\mathbf{C}=\mathbf{S})$ which usually appear in the range $950-1050 \mathrm{~cm}^{-1}$ [22], this band appeared in the IR spectrum of diethyl dithiocarbamate as a very strong band at $985 \mathrm{~cm}^{-1}$ and it appears as a singlet and it suffers a high shift in all complexes spectra. A single strong absorption band in this region is indicative of the symmetrical bidentate coordination of the ligands as mention in introduction (structure $\mathrm{c}$ and $\mathrm{d}$ in page 1).

The spectra of all [M(DTC $\left.)_{2} \mathrm{PAN}\right]$ complexes show band in the region 3404-3470 $\mathrm{cm}^{-1}$ this band was assigned to the uncoordinated protonated $\mathrm{OH}$ group frequency. This band was not existed in the vibrational spectra of free PAN ligand which must be appeared in the range (3570-3450) $\mathrm{cm}^{-}$ 1 [23]. The absence of this band in the free ligand spectra is due to the azo- hydrazo tautomeric form in this molecule[14].

The most characteristic band in the PAN spectrum is the $v(\mathbf{N}=\mathbf{N})$ which appeared at $1402 \mathrm{~cm}^{-1}$. This band was shifted to lower frequency by $\left(\sim 29 \mathrm{~cm}^{-1}\right)$ on complexation giving a good indication for the participation of this group in the coordination with metal ion. Many other bands belongs to azo stretching modes such as the $v(\mathbf{C}-\mathbf{N}=\mathbf{N}-\mathbf{C})$, $\delta(\mathbf{C}-\mathbf{N}=\mathbf{N})$ and $v(\mathbf{N}=\mathbf{N})$ were showed many changes in the complexes spectra Table 3. Far IR spectra of the complexes revealed new bands assignable to $v$ (M-S), $v\left(\mathbf{M}-\mathbf{N}_{\mathbf{p y}}\right)$ and $v$ (M-Nazo) modes.

Thus, on the basis aforesaid arguments the following tentative structures may be assigned for the prepared complexes.

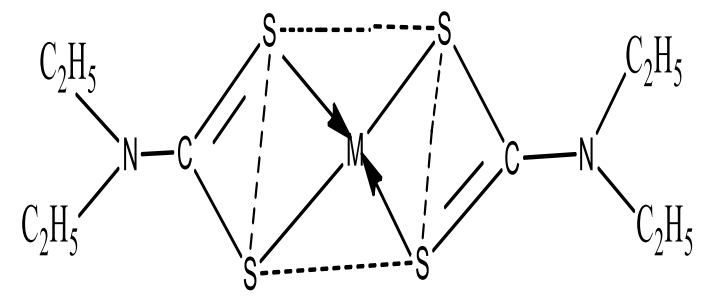

$\mathrm{M}^{\mathrm{II}}=\mathrm{Ni}, \mathrm{Co}, \mathrm{Cu}$

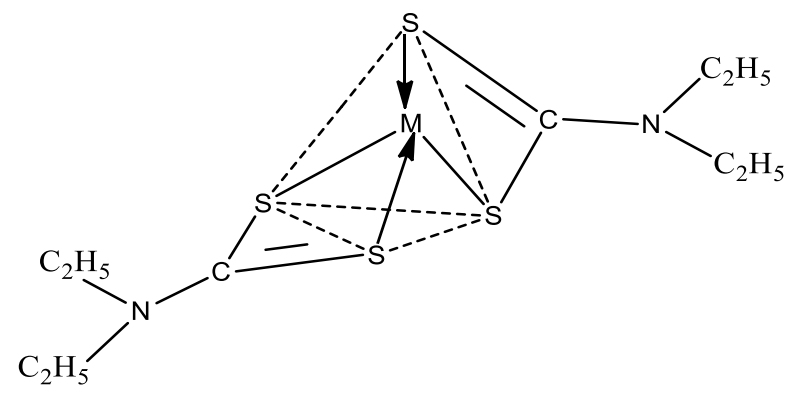

$\mathrm{M}^{\mathrm{II}}=\mathrm{Mn}, \mathrm{Fe}, \mathrm{Zn}$

Fig.(2) The suggested square planar and tetrahedral geometrical structures of the $\left[M^{I I}(D T C)_{2}\right]$ complexes.

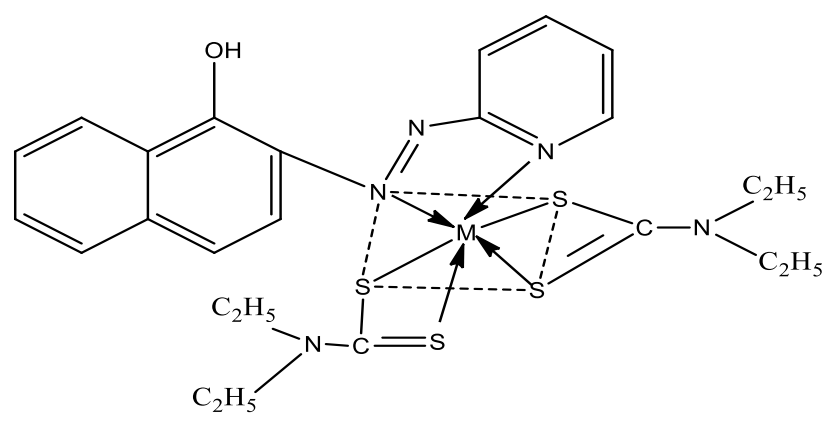

Fig.(3) The suggested Octahedral structures of $\left[M^{I I}(D T C)_{2} P A N\right]$ complexes. $M^{I I}=M n, F e, N i, C o, Z n$. 


\section{3-3: Antibacterial Activity}

The biological activity for the ligands and all the prepared complexes were studied against four selected types of bacteria Escherichia Coli, Pseudomonas (Gram negative) and Staphylococcus Aureus and Bacillus (Gram positive). DMSO was used as a solvent and as a control. The concentrations of the compounds in this solvent were $\left(1 \times 10^{-4}\right.$ $\mathrm{M})$. The Disc Sensitivity Test method was used, The incubated was held for $24 \mathrm{hr}$ at $37^{\circ} \mathrm{C}$. Table 4 listed the deactivation capacity against the bacteria specimen of the prepared compounds under study. The results revealed that most of the metal complexes are potentially more active in comparison with the ligands. The improved activity of metal complexes can be explained on basis of chelation theory. This theory explains that a decrease in the polarizability of the metal could enhance the lipophilicity of the complexes, which leads to a breakdown of the permeability of cells, resulting in interference with normal cell processes [3]. In general, the presence of PAN ligand in the DTCcomplexes increase the inhibition zone.

\section{Table (4) Diameters (cm) of bacteria deactivation of the ligands and their complexes.}

\begin{tabular}{|c|c|c|c|c|}
\hline Compound & E.Coli & $\begin{array}{l}\text { Pseud- } \\
\text { omonas }\end{array}$ & $\begin{array}{c}\text { Bacillus } \\
\text { cereus }\end{array}$ & $\begin{array}{c}\text { Staphy- } \\
\text { lococcus } \\
\text { aureus } \\
\end{array}$ \\
\hline DMSO & - & - & - & - \\
\hline DTC & 1.2 & 1.1 & - & - \\
\hline PAN & 1.3 & 1.2 & 1.4 & 1.7 \\
\hline$\left[\mathrm{Mn}(\mathrm{DTC})_{2}\right]$ & 1.6 & 1.6 & - & - \\
\hline$\left[\mathrm{Fe}(\mathrm{DTC})_{2}\right]$ & 1.4 & 1.7 & 1.3 & - \\
\hline$\left[\mathrm{Co}(\mathrm{DTC})_{2}\right]$ & 1.2 & 1.2 & 1.3 & - \\
\hline$\left[\mathrm{Ni}(\mathrm{DTC})_{2}\right]$ & 1.4 & 1.3 & - & - \\
\hline $\begin{array}{l}\left.\mathrm{Zn}(\mathrm{DTC})_{2}\right] \\
\end{array}$ & 1.3 & 1.4 & 1.2 & $\begin{array}{l} \\
\end{array}$ \\
\hline$\left[\mathrm{Cu}(\mathrm{DTC})_{2}\right]$ & - & - & - & - \\
\hline$\left[\mathrm{Mn}(\mathrm{DTC})_{2} \mathrm{PAN}\right]$ & 1.6 & 1.7 & - & - \\
\hline$\left[\mathrm{Fe}(\mathrm{DTC})_{2} \mathrm{PAN}\right]$ & 1.9 & 1.8 & - & 1.2 \\
\hline$\left[\mathrm{Co}(\mathrm{DTC})_{2} \mathrm{PAN}\right]$ & 1.5 & 1.5 & 1.3 & 1.3 \\
\hline$\left[\mathrm{Ni}(\mathrm{DTC})_{2} \mathrm{PAN}\right]$ & 1.9 & 1.4 & 1.3 & - \\
\hline$\left[\mathrm{Zn}(\mathrm{DTC})_{2} \mathrm{PAN}\right]$ & 1.8 & 1.8 & 1.3 & 1.3 \\
\hline
\end{tabular}

\section{Conclusion}

All the $\left[\mathrm{M}(\mathrm{DTC})_{2}\right]$ complexes responded to the increasing of their coordination number except $\mathrm{Cu}^{\mathrm{II}}$-DTC complex. Stable, colored, non-electrolyte complexes has been obtained by reaction of S,S and N,N ligands . The UvVis and the magnetic susceptibility measurements suggested high-spin octahedral structure for the MII-DTC-PAN complexes, while the IR spectral data indicate the existence of the protonated $\mathrm{OH}$ in the PAN ligand which strongly verify the neutral bidentate behavior of the PAN ligand. The inhibition zone of Gram (+) and Gram (-) bacteria recorded increasing by the addition of PAN to the M-DTC complexes

\section{References}

[1] Amdio E., Cavinato G., Domella A., Ronchini L. Toniolo L. and Vavasori A., "New carboalkoxy bis (triphenylphosphine) palladium (II) cationic complexes: Synthesis, characterization, reactivity and role in the catalytic hydrocarboalkoxylation of ethene. X-ray structure of trans$\left[\mathrm{Pd}(\mathrm{COOMe})(\mathrm{TsO})\left(\mathrm{PPh}_{3}\right)_{2}\right] \cdot 2 \mathrm{CHCl}_{3}$ " Journal of Molecular Catalysis A Chemical Abbreviationn, 298,103-110, 2009.

[2] European Food Safety Authority (EFSA), The European Union Report on Pesticide Residues. EFSA., 9(11): p. 2430, 2011.

[3] Rehman M., Hussain A., Rehman Z., Abdul Rauf F., Hassan, A., Tahir A., Ali S., "New tetrahedral, square-pyramidal, trigonal-bipyramidal and octahedral organotin (IV) 4-ethoxycarbonylpiperazine1-carbodithioates: Synthesis, structural properties and biological applications", Journal of Organometallic Chemistry, 695(10-11), 1526-1532, 2010.

[4] Brown T.L., Lemay Jr. E.H, and Bursten B.E., "Chemistry: The Central Science", $8^{\text {th }}$ Ed. Prentice Hall International, Washington, 2000.

[5] Karlin K.D., "Progress In Inorganic Chemistry", 53, John Wiley and Sons, Inc. New Jersey pp 71, 2005.

[6] Pandeya K.B., Singh R., Mat P.K., "E.s.r. spectra of mixed ligand manganese (II) dithiocarbamates" Transition Metal Chemistry, 11, 347, 1986.

[7] Mohamed G.G., Ibrahim N.A. and Attia H.E.A., "Synthesis and anti-fungicidal activity of some transition metal complexes with benzimidazole dithiocarbamate ligand" Spectrochimica Acta Part A: Molecular and Biomolecular Spectroscopy, 72,610-615, 2009. 
[8] Travinicek Z., Pastorek R. and Slovak V., "Novel octahedral nickel (II) dithiocarbamates with bi- or tetradentate $\mathrm{N}$ donor ligands: $\mathrm{X}$-ray structures of $\left.[\mathrm{Ni} \text { (Bzppzdtc)(phen) })_{2}\right] \mathrm{ClO}_{4} \cdot \mathrm{CHCl}_{3}$ and $\left[\mathrm{Ni}\left(\mathrm{Bz}_{2} \mathrm{dtc}\right)_{2}\right.$ (cyclam)]", Polyhedron 27, 411-419, 2008.

[9] Jayaraju A., Musthak Ahamad M., Mallikarjuna Rao R. and Sreeramulu J. "Synthesis, characterization and biological evaluation of novel dithiocarbamate metal complexes", Der Pharma Chemica, 4 (3), 1191-1194, 2012.

[10] Koh J. and Greaves A.J., "Synthesis and application of an alkali-clearable azo disperse dye containing a fluorosulfonyl group and analysis of its alkali-hydrolysis kinetics; Dyes and Pigments 50, 117-126, 2001.

[11] Wainwright M., "Azo compounds with antimicrobial activity" Dyes and Pigments, 76, 582, 2008.

[12] Karipcin F. and Kabalcilar E., "Spectroscopic and thermal studies on Solid complexes of 4-(2-pyridylazo) resorcinol with some transition metals", Acta. Chimica Slovenica ; 54, 242-247, 2007.

[13] Mohorcic M., Friedrich J., "Tetranuclear $\mathrm{Cu}$ (II) cluster encapsulated in one arsenic (V) heteropolyoxotungstate. spectroscopic and magnetic investigation", Acta Chimica. Slovenica, 5 619-628, 2004.

[14] Mc Naught A. D. and Wilkinson A., "Compendium of chemical terminology", $2^{\text {nd }}$ Ed. (the "Gold Book") Black well Science Inc. (1997).Online corrected version: (2009) "azo compounds".

[15] Silbey R. J., Alberty R. A., and Bawendi M. G., "Physical Chemistry" $4^{\text {th }}$ Ed. JohnWiley, New York,2004.

[16] Stibrany RT., Lobanov MV., Schugar HJ., Potenza JA." A geometrically constraining bis(benzimidazole) ligand and its nearly tetrahedral complexes with $\mathrm{Fe}(\mathrm{II})$ and $\mathrm{Mn}(\mathrm{II})$ " Inorganic Chemistry,43(10): 3322, 2004.

[17] Chandra S., Gupta L. K. "Spectroscopic evaluation of manganese (II) complexes derived from semicarbazones and thiosemicarbazones": Spectrochimica Acta Part A-Molecular and Biomolecular Spectroscopy 61(11), 2549-2554, 2005
[18] Sathyanarayana D.N. "Electronic Absorption Spectroscopy and Related Techniques" Universities press limited (India) 2001.

[19] Costa Jonior A.C., Versiane O., Faget Ondar G., Ramos J.M., Glaucio B. Ferreira, A.A. Martin, C.A. Téllez Soto, "An experimental and theoretical approach of spectroscopic and structural properties of the bis(diethyldithiocarbamate)-cobalt(II)", Journal of Molecular Structure, 1029, 119134, 2012.

[20] Antunes P. A., Bannach G., Chierice G. O., Cavalheiro E. T. G. , "Direct and simultaneous spectrophotometric determination of $\mathrm{Ni}$ (II) and Co (II) using diethanoldithiocarbamate as complexing agent", Eclética Química, 34(2): 7-13, 2009.

[21] Kataria A., Sharma A., Chandra S., "Synthesis, spectroscopic and antifungal studies of $\mathrm{Ni}(\mathrm{II})$ complexes with macrocyclic ligands", Journal of Chemical and Pharmaceutical Research, 2(2), 339344, 2010.

[22] Nakamoto. K. "Infrared and Raman Spectra of Inorganic and Coordination Compounds" $6^{\text {th }}$. Ed. John Wiley and Sons. Inc. 2008.

[23] Gup R. and Giziroglu E., "Metal complexes and solvent extraction properties of isonitrosoacetophenone 2aminobenzoylhydrazone", Spectrochimica Acta Part A-Molecular and Biomolecular Spectroscopy”, 65, 719-726, 2006.

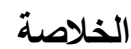

إن ليكاند ثنائي ثايوكاربامات الصوديوم (DTC) كون معقدات ملونة مستقرة من نوع [MTC)

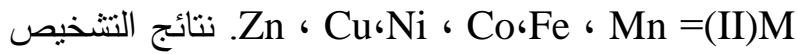
لهذه المعقدات اقترحت الثكل المربع المستوي لمعقدات II Mn شكل رباعـي السطـوح لمعقدات II Cu ,I Ni , IICo

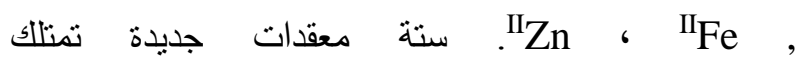

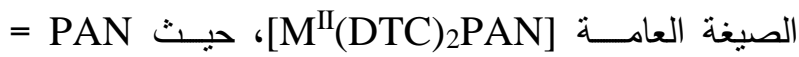
1-(2-بريديل ازو)2- نفتول، حضرت باستخدام طريقتين

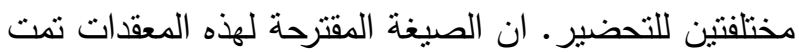


بالاعتماد على النتائج التحليلية والطيفية فضلا عن قياسات

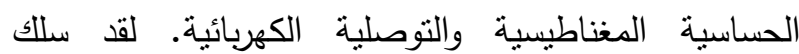
ليكاند DTC سلوكا ثنائي السن مانح من نوع S,S في ولئه جميع المعقدات، كذلك فان PAN ايضا سلك سلوكا ثنائي السن مانح من النوع N,N. إن الاطياف الالكترونية وقيم العزم المغناطيسي اقترحت الثكل ثماني السطوح للمعقدات المحضرة. لقد درست فعالية المضادات البكتريولوجية لليكاندات والمعقدات المحضرة ضد اربع انواع من البكتريا ايشريشيا كولاي Escherichia Coli و بسيدوموناس Pseudomonas Staphylococcus Aureus الغرام البعض من المعقدات كانت استجابته واضحة وبشكل فعال ضد البكتريا كما ان وجود الـ PAN اسهمت في زيادة

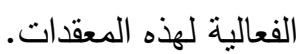

